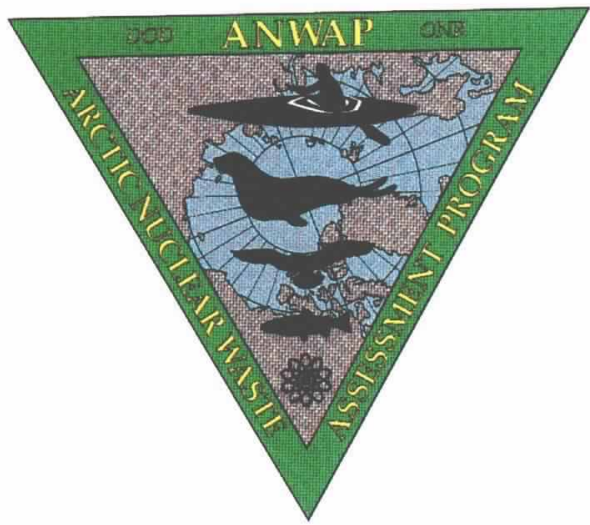

\title{
ThE ARCTIC NuClEAR WASte ASSESSMENT PROGRAM
}

\author{
By R. Edson, G.L. Johnson, L.A. Codispoti, T. Curtin and the ANWAP Science Team
}

$S_{1}$ search has been managing a program of research (in collaboration with the Department of Defense and the Defense Nuclear Agency) that is assessing the fate of radioactive waste material deposited in the Arctic by the former Soviet Union (FSU). This Arctic Nuclear Waste Assessment Program (ANWAP) includes basic and applied research in both the terrestrial and oceanic portions of the Arctic, in adjoining regions in the North Pacific (e.g., the Bering Sea) and in Russia (e.g., the watersheds of the $\mathrm{Ob}$ and Yenisey rivers). This report gives a brief overview of the program and some of its initial results.

\section{Background}

The existence of the ANWAP program stems from the increased information flow surrounding the end of the Cold War. Aided by the efforts of FSU

R. Edson and T. Curtin, Office of Naval Research, 800 North Quincy Street, Arlington, VA 22217, USA. G.L. Johnson, Texas A\&M/Univ Alaska, 4601 Fairfax Drive, Suite 1130, Arlington, VA 22217. USA. L.A. Codispoti, Center for Coastal Physical Oceanography, Old Dominion University, Norfolk, VA 23529, USA. ANWAP Science Team, see Table 2. citizens and by nongovernmental agencies such as Greenpeace (e.g., Handler, 1993), information concerning the dumping of nuclear material into the Arctic Ocean by the FSU became increasingly available during the early 1990s. It soon became evident that considerable amounts of radioactive waste had been deposited in the marine environment contrary to international agreements (London Convention of 1972, The Convention on the Prevention of Marine Pollution by Dumping of Wastes and other Matter) and to the stated policy of the FSU. For example, it was reported in 1991 and confirmed in 1993 in a "white paper" sponsored by the Russian Federation [Government Commission on Matters Related to Radioactive Waste Disposal at Sea ("Yablokov Commission")] that 16 nuclear reactors (of which 7 still contained fuel) and over 10,000 containers of lower level waste had been deposited in the Barents/Kara Sea region (Fig. 1). It was also revealed that smaller amounts had been deposited in the Sea of Japan, the Sea of Okhotsk, and off the Kamchatka Peninsula (Fig. 1). An assessment of the available information by western investigators (Mount et al., 1994) was in general agreement with the Russian Federation Report and suggested that the total amount of activity deposited in the Kara Sea region was from 2.5 to 6 million Curies $\left(1\right.$ Curie $\left.=3.7 \times 10^{10} \mathrm{~Bq}\right)$. It is important to note that the FSU attempted to contain much of this activity by placing the material in steel containers and by surrounding it with other barrier materials. In addition, radioactive decay from the time of dumping to the present will have reduced the radioactivity levels to $\sim 0.5$ million Curies at the present time (Mount et al., 1994).

At about the same time, much more information became available regarding environmental contamination of the Arctic terrestrial environment as a result of nuclear weapons production and fuel reprocessing facilities. These facilities are principally located in the catchment areas of the $\mathrm{Ob}$ and Yenisey Rivers and have released significant quantities of waste directly into the environment. These rivers flow into the Arctic Ocean via the Kara Sea. Although much of this material has already decayed and/or appears to be retained in the watersheds, the total amount that has been released is enormous and has been estimated to be $\sim 3$ billion Curies (Phillips, 1995).

One final source of radionuclide contamination that has also entered into the Arctic area is the direct discharge of ra- 
dioactive waste into the waters of the Irish and North seas by western European fuel reprocessing activities. These facilities are maintained by the United Kingdom and France and operate in compliance with international standards. Despite this compliance, however, and despite a significant reduction in the discharge activity levels, these facilities have together discharged over 3 million Curies (Commission of the European Community, 1989). A portion of this discharge is carried into the Arctic Ocean, and we note that concentrations of Cs137 in the Kara Sea appear to have decreased significantly in concert with decreases in the European discharge.

ANWAP was initiated in 1993 as a result of U.S. Congressional concern over the FSU disposal of nuclear materials into the Arctic marine environment (Murkowski, 1994; Kertulla, 1995). Congress mandated that a portion of the monies made available to the U.S. Department of Defense Co-operative Threat Reduction (CTR) Program (commonly referred to as the Nunn-Lugar program) be employed to assess the disposition of radioactive waste deposited in the Arctic region by the FSU. Specific management of ANWAP is conducted by the Office of Naval Research (ONR) in collaboration with the Defense Nuclear Agency. The selection of ONR was in large part due to its long history of supporting research efforts in the Arctic. ANWAP was able to benefit from over $\$ 500 \mathrm{M}$ of past Arctic research supported by ONR.

\section{OCEAN NUCLEAR WASTE SITES \\ O LIQUID \\ * REACTOR \\ ᄀ SOLID}

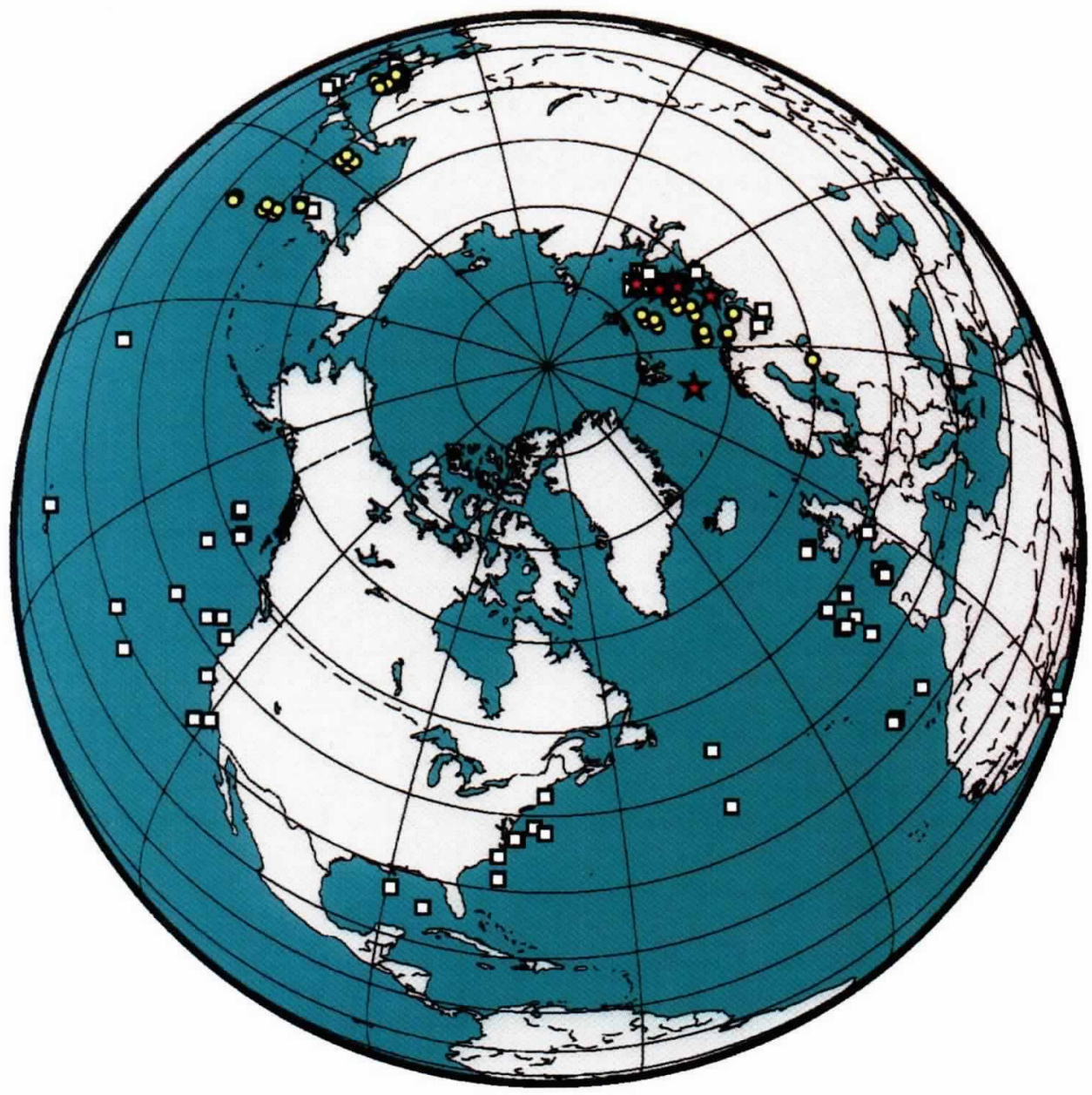

Fig. 1: Location of oceanic nuclear waste sites. This figure was provided by R. Preller of the Naval Research Laboratory.

\section{Program Goals}

The ANWAP program focuses on the following questions.

a. What are the magnitudes and locations of the radioactive wastes that have entered the Arctic (including the N. Pacific) marine environment?

b. How is radioactive contamination transported throughout the Arctic and N. Pacific regions?

c. What is the risk to the environment and to human health as a result of this radioactive contamination?

Additional goals of the program are the development of monitoring strategies for radionuclide contamination in the Arctic and communication with the indigenous populations regarding this study. Of paramount importance in this program are the identification of all significant sources of anthropogenic radioactive contamination to the Arctic marine environment and the ranking of them by their risk to man and the environment.

The program is comprised of $\sim 70$ different projects conducting research of all types: field surveys, laboratory experiments, modeling studies and archival data analysis. The investigators include academic institutions, government laboratories and agencies, industry, and foreign institutions (Tables 1 and 2). Total funding for this project has been $\$ 30 \mathrm{M}$ over 3 years, FY93, FY94, and FY95. Proposal submission has been 10 times available funding levels each year of the program. All proposals were reviewed for scientific and technical merit and for their ability to satisfy programmatic needs. An interagency advisory committee assisted in this review. A list of the agencies and organizations that have participated in the interagency advisory committee is contained in Table 3.

Although ANWAP is unique in that it has a strong emphasis on Alaska, the program also has strong linkages and collaborations with both national and international organizations concerned with Arctic environmental contamination. It has been a priority since the beginning of the program that duplication be prevented and joint projects be initiated when practical. Wherever possible, collaborations with other U.S. agencies have been initiated to ensure the maximum return from the ANWAP projects. 
Table 1

ANWAP project summary
Survey operations

Arctic Basin and adjacent

seas

Arctic river systems

North Pacific

Process studies

Water masses

Ice/contaminant

Barrier material/corrosion

Biological

Biologica]

Physical
Lab experiments

Modeling studies

Near field

River

Estuary

Basin

Database

International

database

Data rescue

Risk assessment

Human health

Ecosystem

Communication

ANWAP. Arctic Nuclear Waste Assessment Program.

Collaborations with scientists and programs in other countries are also important. Collaborating nations include Norway, Sweden, Canada, Germany, Japan, Korea, and the United Kingdom. Of particular emphasis is an attempt to include Russian institutions in this research program, and this cooperation has grown steadily. To date, approximately $10 \%$ of the funds has gone to Russian institutions for research or logistic support, with over $\$ 1 \mathrm{M}$ committed in the 1995 funding cycle.

\section{Scope of Research}

Due to the complexity and diversity of the radionuclide contamination problem in the Arctic region, the ANWAP research efforts cover a large number of topics (Tables 1 and 2) and geographic areas (Fig. 2). As one of its first research efforts, ANWAP initiated a major data retrieval and compilation effort at the Naval Research Laboratory (NRL) as well as at other institutions (Crane, 1995). NRL uses a Geographic Information System to support the analysis of changes in marine radionuclide levels over space and time. This database is being built in collaboration with the Arctic Monitoring and Assessment Program's International Arctic Marine Radioactive Contamination Database in Norway, and the database being developed by the International Atomic Energy Agency. Every attempt is being made to ensure that all data obtained are widely available to the scientific community and that all databases relating to this issue are compatible.

ANWAP survey activities provide the necessary chemical, physical, and biological data to better understand the environ-
Historical data mental processes at work in the Arctic region. These surveys are also aimed at assessing whether the radioactivity dumped into the Arctic Seas or entering the basin via land-based sources present a threat to the Alaskan economy or the health of U.S. citizens. Water, sediment, and biological samples were collected by U.S., bilateral U.S.-Russian, and international cruises in the eastern Arctic near the dump sites and major Arctic river systems, and in the western Arctic near Alaska. To date, $>20$ research cruises have been sponsored (Fig. 2). Activities undertaken in Russian waters generally utilize Russian research vessels and have strong collaborations with Russian scientists.

Unique conditions in the Arctic make process studies important. Ice and sediment dynamics; freeze and thaw cycles; incorporation of sediment into ice; and strong, highly seasonal storm events over a large, shallow continental shelf can influence the distribution and fate of radionuclide contaminants. In addition, the cold-water conditions can affect foodchain interactions and ultimate dosimetry and impact to biota and humans. Projects dealing with Arctic processes include the study of the following:

a. ice uptake and movement of radionuclides and sediment;

b. density driven currents on Arctic shelves;

c. sediment dynamics in the Kara Sea;

d. interactions between colloids and radionuclides in the Arctic river systems;

e. corrosion of disposal barrier materials;

f. identification of sentinel organisms for the monitoring and evaluation of Arctic radionuclide contamination;

g. radionuclide levels, bioconcentration factors, and food chain interaction in Arctic animals;

h. deposition of radionuclides due to interactions with phytoplankton; and

i. sublethal biological effects from radionuclide contamination.

An extensive effort is underway in ANWAP to model the transport of radioactivity from source regions to adjacent seas and the Arctic basin. The mod-
Table 2

List of ANWAP principal investigators*
K. Aagaard, U. Washington
C. Alexander, Skidaway
R. Anderson, DOE/Sandia
T. Beasley, DOE/EML
J. Bischof, Old Dominion University
J. Brooks, Texas A\&M/GERG
E. Callender, USGS
M. Champ. Texas A\&M/GERG
K. Cochran, SUNY, Stony Brook
R. Colony, U. Washington
M. Coon. Northwest Research Associates
L. Cooper, DOE/Oak Ridge
G. Cota. Old Dominion Univ.
D. Dasher, State of Alaska/DEC
R. Dyer, EPA
K. Falkner, Oregon State U.
N. Fisher, SUNY, Stony Brook
S. Forman, Ohio State U.
A. Grantz, USGS
J. Grebmeier, U. Tennessee
C. Hollister, Woods Hole
H. Huntington. Inuit Circumpolar Conf.
M. Jeffries. U. Alaska
M. Johnson, U. Alaska
D. Kadko, U. Miami
J. Kelley, U. Alaska
J. Knezovich, DOE/Lawrence Livermore
S. Kohl, U.S. Fish and Wildlife
D. Layton. DOE/Lawrence Livermore
H. Livingston, Woods Hole
P. Matrai, Bigelow Laboratory
T. McClimans, SINTEF/NHL
B. Molnia. USGS

B. Moran, U. Rhode Island

J. Morison, U. Washington

M. Mount, DOE/Lawrence Livermore

R. Muench. SAIC

A. Munchow, Rutgers

D. Nagel, Naval Research Laboratory

J. Niebauer, U. Alaska

T. O'Hara. North Slope Borough

T. Paluszkiewicz. Battelle

S. Pfirman, Barnard College

N. Pisias. Oregon State U.

R. Preller, Naval Research Laboratory

R. Pritchard, Ice Casting. Inc.

J. Radvanyi, Mississippi State U.

L. Reierson. AMAP Secretariat

A. Robertson, NOAA

P. Schlosser, Lamont Doherty

M. Scott. Texas A\&M

C. Sherwood, Battelle

W. Smethie. Lamont Doherty

D. Smith. U. C. Santa Cruz

J. Smith. Bedford Institute of Oceanography

W. Smith, U. Tennessee

W. Stringer, U. Alaska

J. Swift, Scripps

W. Templeton, Battelle

J. Thiede, GEOMAR

C. Travis, DOE/Oak Ridge

M. Treadwell. State of Alaska/DEC

T. Tucker, CRREL

A. Volpe. DOE/Lawrence Livermore

T. Weingartner, U. Alaska

G. Weller. U. Alaska

\footnotetext{
* Space does not permit listing the many co-PI's who have made valuable contributions.
} 
Table 3

ANWAP interagency advisor committee composition

Central Intelligence Agency

Defense Nuclear Agency

Department of Energy

Department of the Interior

Department of State

Environmental Protection Agency

National Science Foundation

National Oceanographic and Atmospheric

Administration

Naval Sea System Command

Office of Naval Research

Office of the Secretary of Defense

Polar Research Board

U.S. Coast Guard

U.S. Geological Survey

els cover a broad range of spatial and temporal scales, and include marine surface and subsurface layers, coastal currents, estuarine and river water, and ground water (Preller and Edson, 1995). Another area of emphasis is near-field modeling at the dump sites, including the evaluation of sediment distribution coefficients specific to the Arctic environment. Model benchmarking and validation are important elements of this effort.

Monitoring in the Arctic is a complex undertaking, subject to extreme weather conditions and a short field season. A major ANWAP goal is to enhance existing monitoring techniques and technologies and to adapt new ones for the unique Arctic environment (e.g., King, 1995). Another goal is to develop an integrated cost-effective monitoring strategy directed at critical transport and food-chain pathways. While U.S. monitoring efforts are aimed at waters closer to Alaska, ANWAP is also working with Russian investigators to develop monitoring strategies for Russian coastal waters. In 1995, for example, ANWAP initiated support for investigations of the feasibility of monitoring dumped materials in Stepovogo Bay (Novaya Zemlya).
A special effort to synthesize these research efforts into a formal integrated risk assessment was initiated in 1995 . The ANWAP risk assessment activity has as its goal the development and application of models and supporting data to allow for radiological dose calculations to characterize risk to man and the environment. While the initial target group is U.S. populations, the risk to the Arctic environment and the Arctic basin populations as a whole will also be evaluated. This assessment deals only with radionuclide contaminants, but will be developed to allow for a transition to the evaluation of other contaminants if the program mandate is changed. With the tools developed, it will also be possible to evaluate the impact of any future radionuclide releases. The risk assessment will include consideration of extreme events such as river floods, dam failures, and accidents at

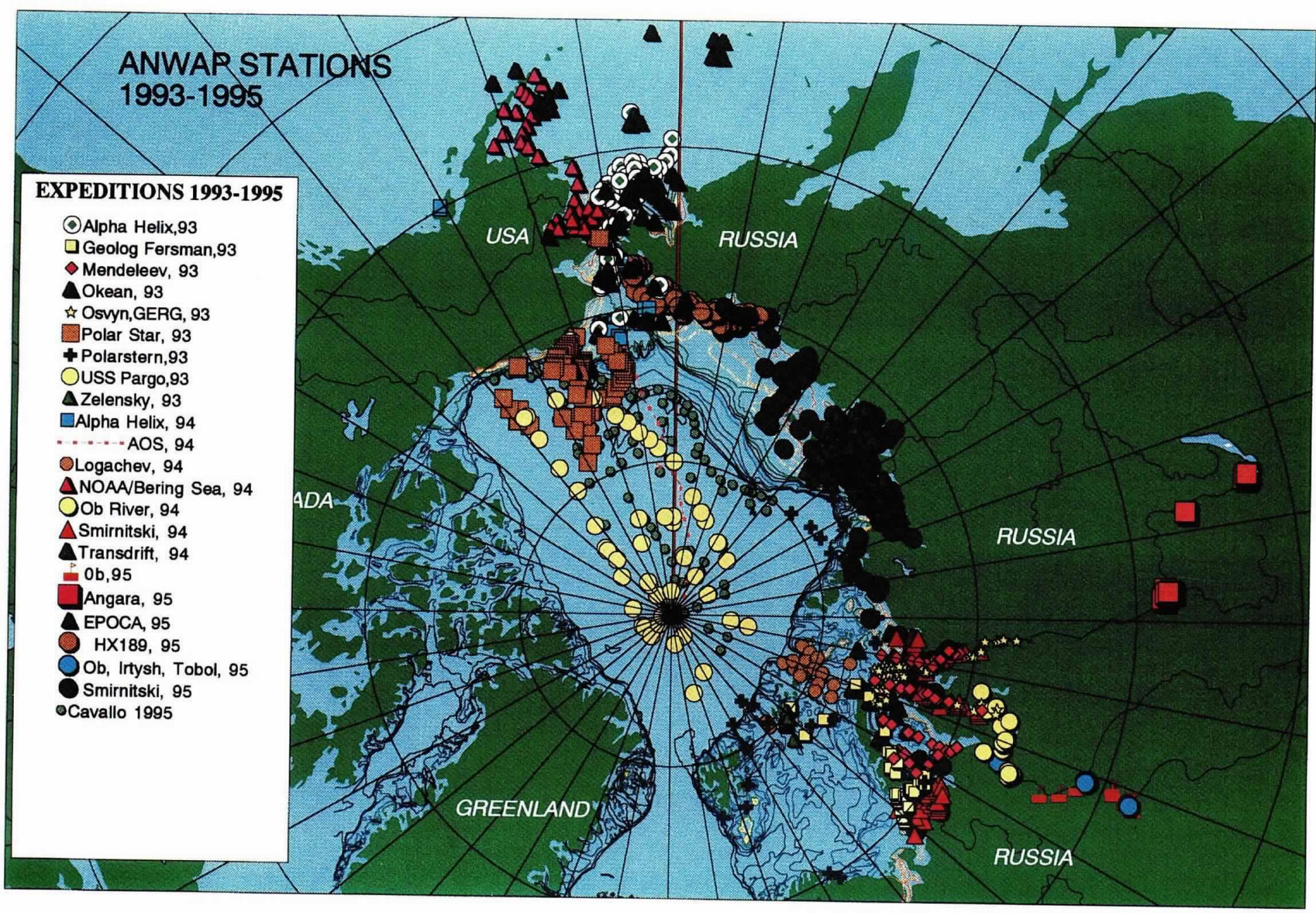

Fig. 2: Location of ANWAP field programs. This figure was provided by K. Crane of the Naval Research Laboratory. 
civilian power plants and related nuclear facilities.

Another output from this portion of the program will be to conduct sensitivity/uncertainty analyses to help guide future research. It is important that those issues having the greatest impact on the risk assessment calculations be given the top priority for research. This analysis will also serve to identify gaps in the existing research plan.

A further goal of ANWAP is the communication of the results of the research and the final risk assessment to the indigenous populations in Alaska, the U.S. public as a whole, U.S. policy makers, and the international community. Interaction with Alaskan native groups is currently ongoing and may involve stakeholder meetings, participation in native conferences, and dissemination of literature. In this area, ANWAP is working closely with the appropriate groups in the U.S. Department of Defense, the Environmental Protection Agency, and the U.S. Department of Interior. Efforts are being made to integrate local knowledge and to address the concerns of the local populations at the onset of the risk assessment phase.

\section{Initial Results}

As the first year's information began to come in, it became evident that there was no significant evidence for widespread radionuclide pollution arising from the dumping of nuclear waste by the FSU. Data produced by the IAEA, by the bilateral FSU/Norwegian surveys in the Barents/Kara sea region, and data produced by ANWAP investigators all suggested that the regional-wide anthropogenic radionuclide signal was fairly low and was decreasing as a result of the cessation of the atmospheric testing of nuclear weapons and the reduction of radioactive effluents from nuclear fuel reprocessing activities in western Europe. A core from the $\mathrm{Ob}$ river system suggests that a signal (which is significantly smaller than the signal from atmospheric testing) is present from the 1986 Chernobyl accident (Panteleyev et al., 1995). Subsequent, studies have revealed some localized zones of high concentrations in Chornaya Bay on the southwestern end of Novaya Zemlya (Forman et al., 1995) where the FSU had performed underwater tests of nuclear weapons, and in Stepevogo Fjord, which is one of the No-

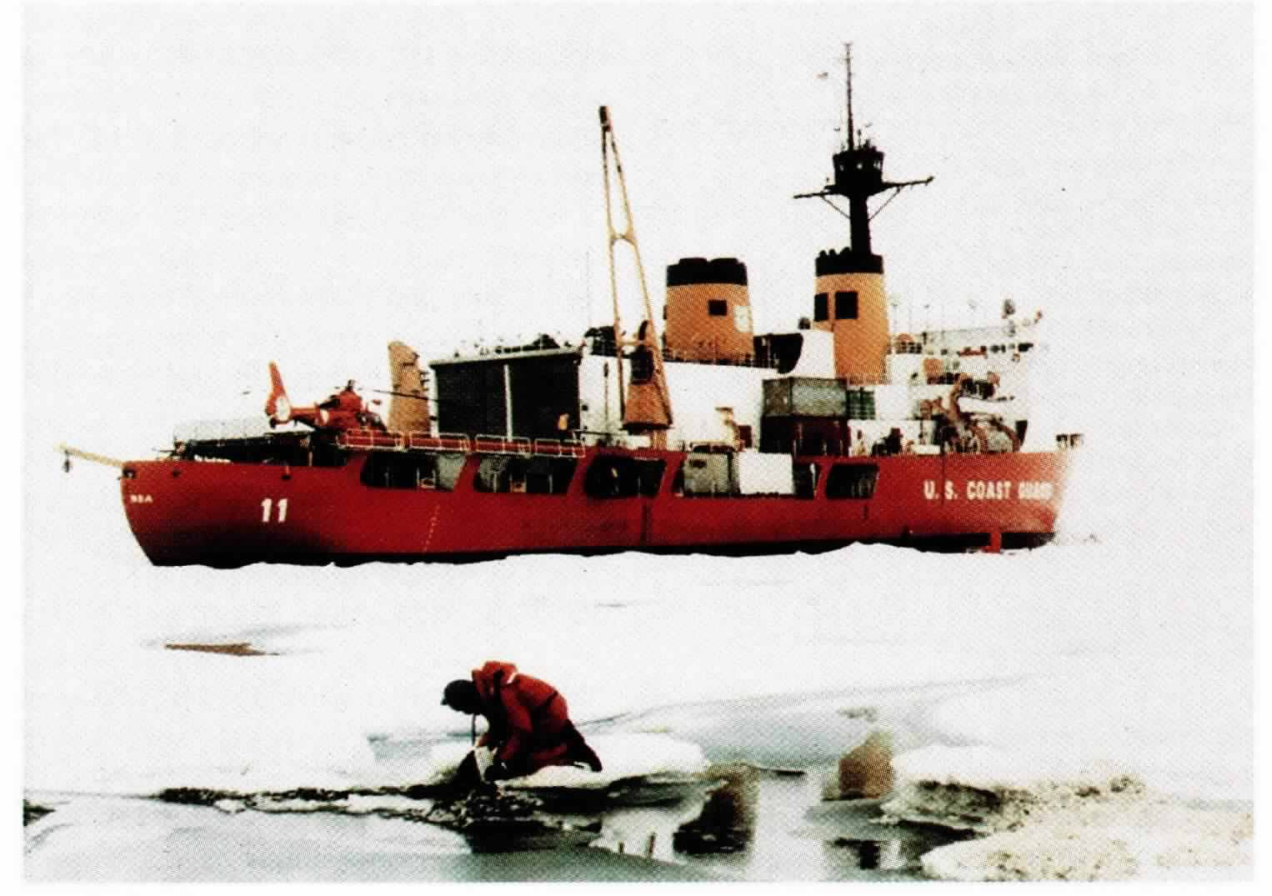

Fig. 3: Sediment-laden ice being sampled during Artic Ocean Section 1994 (AOS-94). This photograph was taken by A. J. Gow of the U.S. Army Cold Regions Research and Engineering Laboratory.

vaya Zemlya fjords where the FSU had dumped nuclear waste material (Foyn, 1995). In addition, there is continued concern about the state of containment of the high level waste (e.g., Timms et al., 1995).

Initial ANWAP results are in line with the contention that Russian rivers are not currently introducing radionuclides to the Arctic Ocean in any great quantity. Some elevated Cs-137 levels ( $80 \mathrm{~Bq} \mathrm{~kg}^{-1}$ dry wt. of sediment) were found near the mouth of the Yenisey river, but they were in the vicinity of the salt wedge where fine grained sediments that tend to have the highest concentrations of Cs-137 might be expected to accumulate (Brooks and Champ, 1995). Overall, Russian rivers do not appear to be making a large contribution at the present time (Baskaran et al., 1995). ANWAP is funding modeling studies that seek to understand the potential for catastrophic releases from the $\mathrm{Ob}$ and Yenisey watersheds during 100 year floods, dam breaks, etc. This work is still in progress (Paluszkiewicz et al., 1995), but a review of the available literature suggests significant decreases in radionuclide concentrations with distance from the sources that tend to lie far upstream. This suggests that the watersheds have a considerable capacity to retain any releases with the possible exception of radionuclides such as strontium-90 that are closely associated with the aqueous phase (Government Commission on Matters Related to Radioactive Waste Disposal at Sea, 1993). Beasely et al. (1995a) found a small but detectable signal in the Canada Basin possibly originating from a source in the $\mathrm{Ob}$ river watershed. At present, it is not possible to state the relative roles of ice, water, or atmospheric transport mechanisms in carrying this signal to the Canada Basin.

An unexpected result from the transCanada basin section that was occupied in 1994 was the discovery of Cs-137 in sediment-laden sea ice found relatively close to Alaska in the Chukchi Sea region (Fig. 3). These samples were taken a significant distance from the Russian East Arctic. This suggests that ice formation processes in the Kara Sea have the potential to entrain $\mathrm{Cs}$ rich fine grained sediments and that some of this material can be transported by ice into the Canadian Basin of the Arctic Ocean (Meese and Tucker, 1995). Alternatively, this Cs could be a signal from Chernobyl or similar accidents.

Turning to waters closer to Alaska, ANWAP results confirmed earlier work 
supported by the Department of Energy and the National Science Foundation, suggesting that anthropogenic radionuclide levels were low and consistent with sources not connected to the FSU dumping of nuclear waste (e.g., atmospheric testing of nuclear weapons). For example, in hundreds of marine sediment samples assayed for Cs-137 between 1990 and 1994, only 14 had concentrations greater than $10 \mathrm{~Bq} \mathrm{~kg}$ ' dry wt. The highest concentration was $12.9 \mathrm{~Bq} \mathrm{~kg}^{-1}$ dry wt and was found in sediments from Pt. Clarence with the probable reason for the relatively high values being the influence of fresh water runoff into this sheltered harbor (Cooper et al., 1995). Plutonium isotope concentrations in the Bering Sea suggest that the major anthropogenic signal is from the era of atmospheric testing (Beasely et al., 1995b), and data from the Anadyr River, which is the largest FSU river flowing directly into the Bering sea. suggest almost pristine conditions with respect to radionuclides (Alexander and Windom. 1995). ANWAP investigators have informally exchanged information with Korean and Japanese colleagues. and ANWAP has helped to sponsor a workshop that included representatives from the FSU, Korea, Japan, and the United States where information was exchanged on a more formal basis (Radjavani. 1995). This information suggests that FSU dumping in the Sea of Japan has not had a widespread effect within the Sea of Japan and is, therefore, highly unlikely to cause a significant signal in Alaskan waters.

\section{Preliminary Conclusions}

The largest signals for region-wide radionuclide contamination in the Arctic marine environment appear to arise from the following:

1. atmospheric testing of nuclear weapons. a practice that has been discontinued:

2. nuclear fuel reprocessing wastes carried into the Arctic from reprocessing facilities in Western Europe: and

3. accidents such as Chernobyl.

Because the signals from 1 and 2 have decreased with time. region-wide concentrations of radionuclides in the water column and in surface sediments appear to have decreased significantly from their peak levels. This assessment remains valid for the Alaskan coastal waters as well. So far. the Yenisey and $\mathrm{Ob}$ rivers appear to have had only a modest impact on radionuclide levels in the Kara Sea and the Arctic Ocean region in general. However, local sites of elevated radionuclide concentration arising from former Soviet Union dumping and weapons testing have been identified in the Kara Sea region, and there is modest concern vis a $v i s$ the possibility of future releases.

\section{Future Activities}

While initial results are encouraging. there still exist scientific issues that must be addressed. Sediment and sea ice processes that affect contaminant transport: time scales of contaminant release: data from winter periods: watershed and river transport of contaminants; and other unique processes in the Arctic are being emphasized in the final funding year of ANWAP and should continue to be investigated. Additionally, quantification of the terrestrial source term and its impact on the marine environment is just beginning. We also need information from the Sea of Okhutusk, the Sea of Japan and from waters adjoining the Kamchatka peninsula. One problem not part of the ANWAP mandate. but that should be addressed, is the problem of other contaminants in the Arctic environment. Radionuclides are just one of the large number of contaminants that could impact the Arctic environment. and it may turn out that other types of pollution such as halogenated hydrocarbons represent a greater threat.

The final result of all ANWAP research will be a formal, integrated risk assessment. As mentioned, this phase of the research began in 1995. The study will address risk to U.S. populations, the Arctic ecosystem, and the other Arctic basin populations. The planned completion of this study is spring of 1997, and the study will be used for the development of efficient. cost-effective monitoring strategies and the formulation of a long-range research plan addressing Arctic contamination.

\section{Acknowledgements}

We dedicate this description of the ANWAP program to Gera Panteleyev, a promising graduate student at the Woods Hole Oceanographic Institution who was so generous with his contributions to ANWAP investigators and so diligent in the pursuit of his own ANWAP research. Gera lost his life as a result of a tragic accident in the $\mathrm{Ob}$ River during the summer of 1995. We also acknowledge all of the ANWAP investigators for their energy and dedication. We have cited much of their work in a cursory way here. but urge the interested reader to consult the more detailed descriptions of their projects that are available from some of the references cited in this report. The principal investigators of the various ANWAP projects are listed in Table 2. We thank Marilyn Varela for providing us with necessary reference material. Finally, we wish to thank the following members of the ANWAP Inter-Agency Advisory Committee who were particularly helpful, Drs. G. Brass, J. Diamonte, C. Myers. E. Myer, C. Newstead, C. Olsen, and P. Webber, Capts. E. Bryant, E. Pope and A. Walker, and Col. R. Dickey.

\section{References}

Alexander, C. and H. Windhom. 1995: Particlebound radionuclide transport to the Bering Sea in the Anadyr River. In: Department of Defense Aretic Nuclear Waste Assessment Program. FY's 1993-94. J. Morgan and L. Codispoti. eds. Office of Naval Research Rept. ONR 322-95-5, 112-115.

Baskaran. M.. S. Asbill. P. Santschi. T. Davis. J.M. Brooks, M.A. Champ. V. Makleyer and V. Khlebovich. Distribution of ". "Pu and "Pu concentrations in sediments from the $\mathrm{Ob}$ and Yenisey rivers and the Kara Sca. Appl. Radiat. $I s o t$. In press.

Beasley, T.M.. L.W. Cooper and J.M. Grebmeier, 1995a: Gamma ray spectroncopy. transuranic radionuclides, lodine-129 and Technitium-99. In: Department of Defense Nuclear Waste Assessment Program. FY"s 1993-94. J. Morgan and L. Codispoti. cds. Office of Naval Research Rept. ONR 32295-5. 2-13.

L.W. Cooper. J.M. Grebmeier. K. Orlandini and J.M. Kelley, 1995b: Fuel reprocessing plutonium in the Canadian Basin. Arctic $\mathrm{Na}$ clear Waste Assessment Works/hop, May 1995. Woods Hole Oceanographic Institution.

Brooks. J.M. and M.A. Champ. 1995: An overview of GERG:s 1993 and 1994 Russian Arctic ANWAP cruises. Arrtic Nuclear Waste Assessment Workshop, May 1995. Woods Hole Oceanographic Invtitution.

Cooper, L.W.. J.M. Grebmeier. I.L. Larsen, K. Ravina and T.M. Beaslev, 1995: Raddionuclide contamination of the Arctic Basin. In: D' partme'nt of Defense Nuclear Waste Assessment Program. FY's 1993-94. J. Morgan and $L$. Codispoti, eds. Otfice of Naval Research Rept. ONR 322-95-5. +2-51.

Commission of the European Communities, 1989: Proccedings: Seminar on the Readiological Expositre of the Population of the Europecan Commumity from Radioactivity in North Earopean Waters. Dircctorate-General. Environment, Nuclear Safety and Civil Protection. Bruges, 1+-16 June 1989.

Crane. K., 1995: Data base need and elforts. In: Proceedings of the ONR/NRL Werkshop on Modeling the Dispersiom of Nuclear Comaminants in the Arctic Seas. R.H. Preller 
and R. Edson, eds. Naval Research Laboratory Rept. NRL/MR/7322-95-7584, 7-37.

Forman, S.L., L. Polyak, J. Smith, K. Ellis, G. Matishov, Y. Bordikov and G. Ivanov, 1995: Radionuclides in the Barents and Kara Sea bottom sediments, distribution, sources, and dispersal pathways. In: Department of Defense Nuclear Waste Assessment Program. FY's 1993-94. J. Morgan and L. Codispoti, eds. Office of Naval Research Rept. ONR 322-95-5, 67-72.

Foyn, L., 1995: Dumped radioactive material in the Kara Sea: Report from three joint Norwegian/Russian Expeditions. Artic Nuclear Waste Assessment Program Workshop, May 1995, Woods Hole Oceanographic Institution.

Government Commission on Matters Related to Radioactive Waste Disposal at Sea ("Yablokov Commission"), 1993: Facts and problems related to radioactive waste disposal in seas adjacent to the territory of the Russian Federation. Office of the President of the Russian Federation.

Handler, J., 1993: Russian nuclear submarine safety, construction, defense conversion, decommissioning and nuclear waste disposal problems. Greenpeace Trip Rept., Greenpeace, Washington, D.C.

Kertulla, A., 1995: United States responds to Soviet nuclear waste. Witness the Arctic, 8, 2 (Arc- tic Research Consortium of the United States, Fairbanks, AK).

King, S.E., 1995: Proceedings of the Workshop on Monitoring of Nuclear Contamination in Arctic Seas. Naval Research Laboratory, Rept. NRL/MRL/6610-7674.

Meese, D. and W.B. Tucker, 1995: Radionuclide contaminants in central arctic sea ice. In: Proceedings of the ONR/NRL Workshop on Modeling the Dispersion of Nuclear Con. taminants in the Arctic Seas. R.H. Preller and R. Edson, eds. Naval Research Laboratory Report NRL/MR/7322-95-7584, 53-59.

Mount, M.E., M.K. Sheaffer and D.T. Abbot, 1994: Estimated inventory of radionuclides in Former Soviet Union Naval Reactors Dumped in the Kara Sea. Arctic Research of the United States, 8, 160-178.

Murkowski, F.H., 1994: The environmental legacy of the Cold War. Arctic Research of the United States, 8, 9-12.

Paluszkiewicz, T., L.F. Hibler, M.C. Richmond and P. Becker, 1995: An assessment of the flux of radionuclide contamination through the $\mathrm{Ob}$ and Yenisey rivers and estuaries to the Kara Sea. Arctic Nuclear Waste Assessment Program Workshop, May, 1995. Woods Hole Oceanographic Institution.

Panteleyev, G.P., H.D. Livingston and F.L. Sayles, 1995: The history of plutonium and cesium-
137 contamination of Ob River delta sediments. Arctic Nuclear Waste Assessment Program Workshop, May 1995, Woods Hole Oceanographic Institution.

Phillips, G.W., 1995: Monitoring workshop introduction. In: Proceedings of the Workshop on Monitoring Nuclear Contamination in Arctic Seas. S.E. King, ed. Naval Research Laboratory Rept. NRL/MR/6610-95-7674, 2-8.

Preller, R.H. and R. Edson, 1995: Proceedings of the ONR/NRL Workshop on Modeling the Dispersion of Nuclear Contaminants in the Arctic Seas. Naval Research Laboratory Rept. NRL/MR/7322-95-7584.

Radvanyi, J. 1995: Workshop results: Japan-RussiaUnited States study group on dumped nuclear waste in the Sea of Japan. Sea of Okhotsk and the North Pacific Ocean. Arctic Nuclear Waste Assessment Program Workshop, May 1995, Woods Hole Oceanographic Institution.

Timms, S.J., N.M. Lynn, M.E. Mount and Y. Sivintsev, 1995: Modelling the release to the environment in the Kara Sea from radioactive waste in the dumped reactor compartment of the icebreaker Lenin. In: Proceedings of the ONR/NRL Workshop on Modeling the Dispersion of Nuclear Contaminants in the Arctic Seas. R.H. Preller and R. Edson, eds. Naval Research Laboratory Rept. NRL/MR/7322-95-7584, 268-293. 